\title{
WILLIAM SNYDER HALL: IN MEMORIUM
}

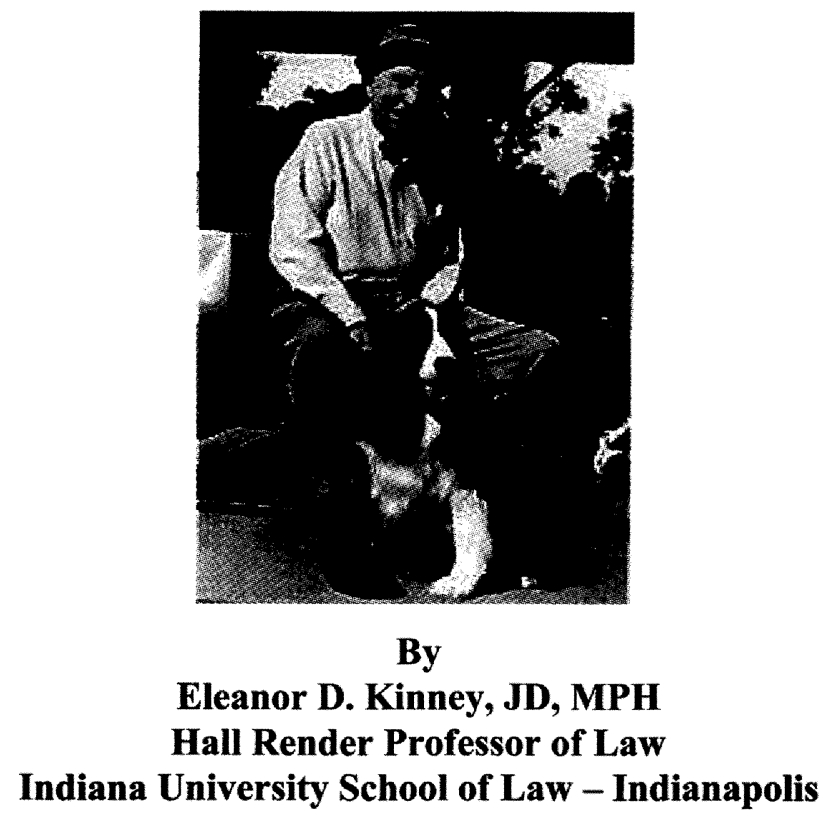

The academic program in health law at Indiana University School of Law - Indianapolis has lost one of its best friends, Bill Hall. William Snyder Hall, age 93, of Indianapolis, passed away Sunday, October 24, 2004.

The Center for Law and Health was named in honor of Bill Hall and his wonderful wife Christine S. Hall just last fall, 2004. How this came to pass is indicative of the kind of man Bill Hall was as well as the kind of friend Bill Hall was to his alma mater. More later on this story.

Bill Hall was born December 15, 1910 in Brazil, Indiana, the son of the late I.G. Hall and Helen Louise (Snyder) Hall. Mr. Hall attended public school in Brazil, Indiana until moving to Indianapolis in the 1920s. He graduated from Park School in 1929 and then attended the University of Pennsylvania, Wharton School, graduating in 1933 with a B.S. degree in Economics and Finance.

Bill Hall started in business at an auspicious time - the 1930s. He was in the oil and gas business in Texas until 1941 - just after the Supreme Court's famous decision on delegation of legislative power, Panama Refining Co. v. Ryan, 293 U.S. 388 (1935), that concerned the Texas oil industry. From 1941 to 1944 , Bill Hall was in the chromium business in Oregon.

In mid-career, like so many of our students, Bill Hall decided to attend law school. He came back home to Indiana and went to night school at Indiana University Law School. He graduated with a J.D. degree in June 1951. Following his graduation, he practiced law in Indianapolis with the law firm of Dowden, Denny, Caughran \& Lowe until the mid-1960s.

Bill Hall was the first health lawyer in the state of Indiana and, indeed, one of the first in the nation. Health law was an unknown field before the 
1960s. The inauguration of the Medicare and Medicaid programs in 1965 changed all that. With these programs, the number and complexity of health care institutions grew in leaps and bounds given the infusion of very generous payment for services and the pent up demand for health care among the elderly and disable. Bill Hall was present at the creation, saw the opportunity and ran with it in the tradition of the best of creative lawyers.

Bill Hall's accomplishments in health law are legion. In 1967, he founded the law firm of Hall, Render, Killian, Heath \& Lyman. Hall Render, which has focused its practice primarily in the area of health law and is one of the nation's preeminent health law firms. Bill served as General Counsel to the Indiana Hospital \& Health Association (formerly Indiana Hospital Association) since 1960. He taught public health law at the Indiana University School of Medicine and served on state commissions for health law reform. Bill Hall was also involved with some of the most important Medicare litigation of his day working creatively to establish the system for federal payment for hospital services for Medicare beneficiaries in ways that assured high quality care for Medicare beneficiaries and the continued growth of hospitals and their teaching and research missions.

Not surprisingly, Bill Hall was recognized and honored by many on many occasions. His preparatory school, Park Tudor (formerly the Park School), honored him as outstanding alumnus just this year. Mr. Hall was the recipient of the distinguished Sagamore of the Wabash award on two occasions, October 3, 1979 from Republican Gov. Otis R. Bowen and December 2000 from Democrat Gov. Frank O'Bannon. He was also awarded the Distinguished Hoosier award in 1994 from Gov. Evan Bayh. As a member of the Indiana State Bar Association for 50 years, he received its attorney Golden Career Award on October 4, 2002.

On November 10,2003, he and his wonderful wife, Christine, received yet another honor. In their honor, the shareholders of Hall Render contributed the funds to remodel space in the law school for a fabulous, state-of-the-art space for the Center for Law and Health and the Indiana Health Law Review. The story about how this came all came about bears witness to the kind of man Bill Hall was and why we are so incredibly proud to have his name and that of Chris Hall's affixed to the Center for Law and Health.

Bill Hall was acutely aware that everyone needs the help of others to reach their goals. He always appreciated the help that his law school had provided him in becoming a lawyer. He was a generous contributor to the law school financially and funded the Hall Render Professorship which is my honor to hold. He was incredibly generous to students and associates with his time, advice and willingness to share his experiences with a health law class.

I recall a time that I was writing a report for yet another Indiana health reform commission and wanted a section on the contributions of public hospitals. I sent a student over to see Bill Hall to get background information. Three hours later, the student returned wide-eyed from his afternoon with Bill Hall. Bill had traced the story of public hospitals in Indiana, his involvement in rewriting the statutes regulating public hospitals and locating public hospitals in the overall mission of the health care sector. 
Bill Hall was generous to everyone who came his way. For example, he worked for an organization that placed high school drop outs in summer internships with health care institutions with the view to getting them back on track. He had a special relationship with a former coordinator of the Center who worked with him to take on interns at the center to gain job skills and confidence under her protective wing.

I loved being Bill Hall's "professor." In academia, it is generally thought better to hold a chair contributed by one who has passed on rather than one who is still here. I have colleagues in the later group who are constantly critiqued by their benefactors to the point of distraction. Bill was my critic in the best sense of the word. He would call and write from time to time. He would ask about various matters, give advice and just make sure I was on the right path. He would habitually refer to me as "my professor." I loved it. I appreciated the guidance and the fact that he cared in our enterprise. Now I miss his "interference" terribly.

He cared about our work at the Center. When he heard about the need for funds to remodel the space for the Center for Law and Health, he promised to guarantee the funds that we would raise from others so that we could begin construction immediately. It was then that his partners stepped in with their well-deserved surprise.

It is an honor for the law school to have the opportunity to name the Center for Law and Health, the William S. and Christine S. Hall Center for Law and Health. Chris is a wonderful person with her own fine story. Bill's story is wonderful too. He conducted his career and lived his life with the knowledge of who put him here on earth and why. We do and will miss him. 